\title{
EFL Learners' Attitude towards Developing Speaking Skills at the University of Taif, Saudi Arabia
}

\author{
Abdul Fattah Soomro ${ }^{1} \&$ Muhammad Umar Farooq ${ }^{1}$ \\ ${ }^{1}$ English Language Centre, Deanship of Supportive Studies, Taif University, Taif, Saudi Arabia \\ Correspondence: Abdul Fattah Soomro, English Language Centre, Deanship of Supportive Studies, Taif \\ University, Taif, Kingdom of Saudi Arabia. E-mail: a.nizamuddin@tu.edu.sa
}

Received: January 18, 2018

Accepted: February 4, 2018 Online Published: February 21, 2018

doi:10.5539/ijel.v8n3p318

URL: http://doi.org/10.5539/ijel.v8n3p318

\begin{abstract}
Speaking is the most difficult as well as the most complex of all the four skills, as it requires expertise in, and exposure to, the target language. Different factors are found responsible for poor speaking skills among EFL learners in general and Saudi EFL learners in particular. The current study investigates the influence of various factors related to teachers, learners, and learning environment on the students' attitude towards learning speaking skills. The questionnaire survey was employed to elicit responses from 184 undergraduate EFL male and female students in Taif University. Data analyzed through SPSS reveals that out of five variables only one was insignificant, whereas all other variables showed significant positive effect. In the light of the findings, it could be inferred that lack of measures on the part of teachers and learners as well as the classroom setting/environment do not fully facilitate both the male and female students to learn speaking skills in a better way. The poor level of their skills in English is attributed to the variety of teachers', learners', and environment related factors. And these factors affect negatively on the attitude of learners towards learning speaking skills.
\end{abstract}

Keywords: pedagogical practices, teachers' related techniques and strategies, learners' attitude, learning environment, experience of speaking skills

\section{Introduction}

Communication in L2 teaching and learning is becoming the focal point as both a process as well as the main objective of L2 learning (Yashima, 2002). MacIntyre et al. (1998) supports this idea by remarking that the ultimate objective of L2 learning should be to prepare the language students to be able to utilize the language for the purposes of communication as per demand of leaners who consider the ability to speak English as a main objective in L2 setting. Richards \& Renandya (2002) maintain that a large numberof the language learners in the whole world come to study with the intention of developing proficiency in speaking English. Nevertheless, leaners face a great deal of difficulty in developing this ability. In this regard, Celce-Murcia \& Olshtain (2000) mention that speaking is the most difficult as well as the most complex of all four skills as it requires expertise in grammatical patterns, vocabulary retrieval and sociocultural competence. The chances of gaining proficiency become lesser when the leaners don't have much or no access to the target language in the class as well as outside it (Pawlak, Waniek-Klimczak, \& Majer, 2011). Anxiety is accounted for leaners unable to develop better speaking skills (Horwitz, 2008). The language anxiety does not only affect learners, it also affects the teaching skills of non-native teachers of English who get very anxious about speaking, thus they skip conversational activities and don't adopt communicative teaching methods (Li, 1998; Littlewood, 2007). Different explanations have been offered by second language acquisition theories on how to develop oral language/speaking skills, however no shift has yet been noticed in the pedagogical practices of teaching oral skills to leaners. There is also growing interest in the debate about which method is better/best to teach speaking skills.

\section{Literature Review}

\subsection{Factors Affecting the Students' Learning English Speaking Skills}

\subsubsection{Teachers-Related Factors}

As mentioned earlier, communication is the goal for learning a language. Apart from many factors that contribute to teaching and learning of speaking skills, teachers-related factors that affect students' English speaking ability are worth mentioning. In this regard, Chot (2015) believes that the teachers are not quite aware of the desire of 
their students regard to improving their pronunciation in English and the challenges students confront with in communication. In addition, it's also observed that no sufficient time is spared for conducting various exercises and creating opportunities so that learners may improve speaking skills. Students are heard making complaints of scolding, and demotivation by their teachers when they make mistakes while speaking in the class.

Teachers must take into consideration the language proficiency of their respective leaners when they construct a speaking activity. If the language proficiency is not known and we give them a difficult task to perform, this would result in demotivation and frustration. The students communicate a lot in the target language in the successful speaking tasks. It is observed that one of the common problems with speaking skills is that the students just produce one or two utterances in the target language and then resume talking in the native languages because the tasks are either difficult or not interesting. Another issue is teachers' too much talking in the class and consuming almost all time and leaving just a few minutes for students to practice language in the class (Ur, 1996). The teachers have a vital role in the in the spreading of foreign language as they provide students with the opportunities where they could express themselves in the proper context. Nunan \& Lamb (1996, p. 134) indicate that the teachers' roles are not static; they keep on changing, because of the psychological factors that the participants bring in the classes. Likewise, Byrne (1991, p. 13) resembles the teacher with an actor who keeps on changing roles. A teacher is supposed to play different roles at different times.

Harmer (2001, p. 104) maintains that the response to students' performance rely on the level of lesson being taught, the nature classroom tasks, the needs of the particular students. Different researchers have different paradigms to provide feedback; it is quite often that feedback is viewed from the accuracy (type of the language utilized) and fluency (content of spoken output) activities. Byrne (1991) and Harmer (2001) hold the view that the feedback on participants' spoken language shouldn't be either positive or negative but focus on creating an environment to enhance their motivation. They differentiate between the feedback on the basis of "form" and on "content", recommending strategies and decisions to be taken in mind for both types. The strategy suggested by them for feedback on the basis of content or form incorporates: it is essential that the teacher should not interrupt in "mid-flow", since it hinders the communication and drags the task back to restart. That is why gentle correction needed to be used, for example, encouraging students to come forward, appreciating a correct response, rephrasing what a student utters, praising, explaining or modifying a candidate's answer, summarizing, repeating, providing feedback and recording mistakes for future analysis.

\subsubsection{Students-Related Factors}

Though students know the significance of involving themselves in the class based activities, however they rely heavily on the teacher for creating communication opportunities so that they get chance to use target language in the class (Ramirez, 2010). Students feel hesitated to speak inside or outside of the class in the target language. They feel anxiety while it comes to using English out of the class room, and in other way, they are perfunctory to speak English ones they are in the classroom. Lin, (1998) makes it clear that still learners feel reluctant to speak fearlessly in the class because they consider teacher to be an authoritative figure.

Students play a vital role when it comes to assigning speaking skills beside the teachers' role. They are supposed to involve in teaching and learning activities in various ways. One of the most essential advancement towards more communicating oriented language learning teaching has been the involvement of the learner in the process (Wenden, 1991). Cotterall \& Crabbe (1999) hold a view that in formal education system the most success finding students are those who are independent learners and ready to accept responsibility; they keep on giving feedback on what they have been learning and have learnt so far. Scharle \& Szabo, (2000) indicate that the autonomous learners are those who stand to take their responsibilities and feel accountable for their language learning and feel it important to have own efforts and act accordingly. When it comes to class work, homework and activities, "they (students) are not in rush to please merely their teacher for good marks but keep on learning through the class. They cooperate with teachers andother groups in the class for everyone's benefit." (ibid, p. 21) Hedge (2001)maintains that an autonomous learner is particularly the one who is self-motivated, accepts responsibilities, takes initiatives, and holds a vivid concept of what is to be learnt by makes plans for pursuing it.

Kohonen et al. (2001, pp. 36-37) emphasize that learners are required to develop the given types of capabilities: self-control, curiosity, communication, cooperation, confidence, relatedness and intentionality. Confidence: sense of having control of one's physical body and behavior in the world. Curiosity: Hankerings to find out things. Intentionality: ability to work with persistence and competence. Self-control: capability of altering and controlling one's movement properly. Relatedness: ability to involve in dialogue with others. Communication: ability to talk with others, to interchange concepts, experiences, and grasp ideas. Cooperation: maintain others' needs within the group. However, it is almost impossible to learn language unless they use it inside and outside 
of class. This is because the language learning process is a very complex phenomenon in the classroom (Harmer, 2001). Further, she maintains that in order to learn language and compensate with class timings one has to develop own plans and strategies to learn language so that one becomes an autonomous learner. In order to develop their autonomy, teacher has to play a role by making them aware of their self-learning and understanding (Kohonen et al., 2001).

\subsubsection{Learning-Environment Related Factors}

Learning place refers to multiple physical venues, cultures, and contexts in which students learn. It incorporates the particular culture of school or class. The most of the important characteristics involve individual's interaction, how the treat each other and the way teachers design and organize educational facilities to assist learning. Cotter (2007) elaborates that the role paly activity assigned by teacher to students in which students are involved, results in effective learning of target language. Moreover, it is also essential for developing a positive environment to enhance students' interaction. So that they could elaborate their ideas, concepts, views, and feelings without the fear of committing mistakes. Students could also keep on carrying out tasks effectively. Chot (2015) recommends that developing a natural environment for learning with less stress and incorporating language for practical and real situations helps in developing meaningful discourse and learners have a possible opportunity to acquire discourse skills. Furthermore, Gutiérrez also suggests other essential components for language learning are exposure, motivation and use. With such a view of language, the task based language learning provides a lot of advantages in preparing of communicative tasks and their enhancement and in improvement of spoken skills. A cooperative and conducive environment is developed by the teacher on a number of occasions. Such situations provide vital social as well as practical platform for students, in particular for ESP students.

\section{Conceptual Framework}

The number of approaches, which have been used to investigate the second or foreign language speaking, falls into three categories: cognitive, discourse analysis, ethnographic. Cognitive approach covers the psycholinguistic perspective on how language is produced by non-native speakers. According to this approach, there is difference in the processes/mechanism of speech production by native as well as non-native speaker of a language. Speaking a language that is foreign is a challenging task as it requires having smooth production, automated underlying processes (Levelt, 1989; Bygate, 1998). Skehan $(2001,2009)$ agrees that speaking is a complex skill which drops a large burden of tackling fluency, accuracy and complexity on a learner. Discourse analysis focuses on developing effective strategies from natural spoken interactions of native speakers for facilitating spoken communication in English (Burns, 2001; McCarthy \& O'Keeffe, 2004). The main goal of this approach is to develop knowledge about how to ask for things, ways of doing things in proper manner, and developing skills for producing interaction and managing it, the rules of conversation and its structure, functions and meaning by examining the different features and various structures of natural spoken discourse (Burns \& Seidlhofer, 2010). Ethnographic approach focuses on exploring the impact of external social and motivational factors on the development of speaking skill (Bygate, 1998; Morita, 2000). Ethnographic studies investigate the impact of social relations of power in creating the possible opportunities for language learners to speak, nature of conditions/environment in which language learners try to speak, the role of pedagogic practices in helping language learners to develop this skill (Norton \& Toohey, 2001) and the personal effort of the speaker in using the target language (Norton, 1995, 1997).

A number of studies have investigated the difficulties and concerns of ESL students in oral skills, (e.g., Ferris, 1998; Cao, 2011; Kim, 2006; Ferris \& Tagg, 1996; Yang, 2010). The focus of the most of these studies, however, has been on international students studying abroad at English Speaking countries or in the academic environment which is dominantly English. Some of the studies are worth mentioning such as Evans \& Green's (2007) research investigating into the problems of language learners at a Hong Kong university and a study by Liu \& Jackson (2008) which examines anxiety faced by undergraduate students in oral English classrooms at a university in China. According to Liu \& Jackson (2008), anxiety is a serious issue in oral English which needs to be addressed by developing effective strategies to minimize anxiety-provoking causes among the learners so that they may achieve language fluency- the final goal of teaching and learning in a classroom. According to Akasha (2013), there is a lack of research investigating learners' experience of speaking English in the EFL context of KSA. Some studies relevant to this indicates number of issues. Arabic-speaking ESL students face both linguistic and cultural problems (Akasha, 2013). A research study conducted by Al-Khresheh (2010) concludes that Arab EFL leaners face difficulty in the order of words while using a simple sentence of English. There are a few negative and positive transfers which hinder and facilitate the leaners to acquire English Language skills (Palmer et al., 2007). 
As such there is no much literature available to guide us to know which factors are really responsible for poor speaking skills among the learners. This study seeks to evaluate the effectiveness of current pedagogical practices being used by English teachers at TUELC while exploring the nature of learners' difficulties and challenges in developing such skills and contribute to the existing literature on the topic. The lack of research about leaners' experience of speaking skills is a main problem. The current study aims to fill in this gap by exploring the impact of various factors: teachers' related, students' related and learning environment related.

\subsection{Research Hypothesis}

1) There is a positive relation between the techniques used by the teachers and the students' attitude towards learning speaking skills.

2) There is a positive relation between the strategies used by the teachers and the students' attitude towards learning speaking skills.

3) There is a positive relation between the strategies used by the teachers and the students' attitude towards learning speaking skills.

4) There is a positive relation between the difficulties faced by the students and their attitude towards learning speaking skills.

5) There is a positive relation between the learning environment and the students' attitude learning speaking skills.

\section{Research Methods}

\subsection{Instrumentation}

The present study employs questionnaire survey to develop understanding about the issue under inquiry. The questionnaire was adopted from the study conducted by Chot (2015). However, the researcher adapted it in the light of contextual realities after reviewing a vast literature related to the topic. The questionnaire consists of four sections. Part (1) is related to the demographic data of the participants. Part (2) of the questionnaire inquires about techniques and strategies used by the teachers to teach speaking skills. Part (3) of the questionnaire investigates students-related factors such as strategies used by the learners, their attitude and difficulties in developing speaking skills. Part (4) of the questionnaire is about the learning-environment related factors.

\subsection{Sampling}

Since the findings of the current study are based on the perception and views of 184 EFL male and female students in Taif University. 250 questionnaires were distributed among male and female students. To ensure the valid representative sample from the target population, the stratified random sampling was applied. In the beginning, the whole population was divided into two strata: Male and Female. Then, each of these two strata was further distributed into five more streams: Humanities, Science, Medicine, Engineering and Business. Twenty five questionnaires were randomly distributed in each of five streams in both male and female campuses. The researcher received 184 questionnaires out of 250 from both the campuses.

Table 1. Sampling mechanism of recruiting the participants and response rate

\begin{tabular}{lllll}
\hline Gender wise distribution & & Stream & Questionnaire Distributed & Response \\
\hline Male 99 (79.25) & Female 85 (68\%) & Humanities & 50 & $40(80 \%)$ \\
& & Science & 50 & $38(76 \%)$ \\
Semester wise distribution & & & $42(82 \%)$ \\
& & Medicines & 50 & $30(60 \%)$ \\
First 91 (72.8\%) & Second 93 (74.4\%) & Engineering & 50 & $34(68 \%)$ \\
& & Business & 50 & $184(73.6 \%)$ \\
\hline
\end{tabular}

\subsection{Data analysis Techniques}

Data was analysed through SPSS. The results are being presented through Descriptive analysis, The Pearson correlation, One-way ANOVA and Independent Samples T Test. For checking the psychometric reliability and validity, the measurement items were factorized using exploratory factor analysis (EFA) with the maximum likelihood (MLE) method. The instrument also captured the demographic information of the respondents. All 
items were measured on the five-point Likert scale, anchored by strongly agree to strongly disagree, except for the demographics, which were measured on a nominal scale.

\section{Results and Discussion}

There are three sections of the questionnaire: Teachers' related factors, students' related factors and learning related factors. In teachers' related factors, the respondents were asked to tell about the techniques and strategies used by the teachers for teaching speaking skills. In students' related factors, learners were investigated about the strategies used by them, their attitude and difficulties in developing speaking skills. In learning related factors, student-participants were asked to share their opinion and views about classroom setting and availability of facilities for practicing speaking skills. The summary of the results in mean value for each of the section of questionnaire is first presented.

The techniques used by teachers comprises of thirteen questions adopted from the study of Chot (2015). Reliability of the construct is .80 (i.e., $80 \%$ ) which is well above than the required value, i.e., 0.60 (Cronbach, 1951; Nunnally, 1978). Overall mean of all the thirteen items is 2.538 with variance of 1.103 which states that opinion of the respondents was moderate on techniques used by teachers. The strategies used by the teachers comprises of 6 questions. Reliability of the construct is .72 (i.e., $72 \%$ ) which is well above than the required value, i.e., 0.60 (Cronbach, 1951; Nunnally, 1978). Overall mean of all the six items is 2.46 with variance of 1.208 which states that the teachers do not quite often use strategies. The strategies used by students comprises of 5 questions. Reliability of the construct is .86 (i.e., $86 \%$ ) which is well above than the required value, i.e., 0.60 (Cronbach, 1951; Nunnally, 1978). Overall mean of all the five items is 2.64 with variance of .037 which suggests that students do not use these strategies. Learners' attitude towards learning English speaking skills comprises of 5 questions. Reliability of the construct is .77 (i.e., $77 \%$ ) which is well above than the required value, i.e., 0.60 (Cronbach, 1951; Nunnally, 1978). Overall mean of all the five items is 2.55 with variance of .095 which suggests that students' attitude towards learning is not very positive. Students' difficulties in learning English speaking skills comprises of 9 questions. Reliability of the construct is .77 (i.e., $77 \%$ ) which is above than the required value, i.e., 0.60 (Cronbach, 1951; Nunnally, 1978). Overall mean of all the 9 items is 2.6 with variance of .016 which suggests that feel difficulties in English speaking skills.

For looking at the mean difference between Gender (male vs. female) and Semester (first vs. second), the independent-sample t-test was examined. Results reveal that in terms of grouping variable gender only significant difference was observed in the scores of SUBS. More specifically, score for the males were $\mathrm{M}=2.9798, \pm \mathrm{SD}=.72111$, and females were $\mathrm{M}=2.7118, \pm \mathrm{SD}=.78822 ; \mathrm{t}(184)=2.391, \mathrm{p}=.018$, two-tailed. From the mean score it shows that male were more reluctant compare to the female in perceiving SUBS (i.e., $1=$ strongly Agree to $5=$ strongly disagree).

Table 2. T-test for equality of means

\begin{tabular}{|c|c|c|c|c|c|c|c|}
\hline & $\mathrm{t}$ & df & Sig. (2-tailed) & $\begin{array}{l}\text { Mean } \\
\text { Difference }\end{array}$ & $\begin{array}{l}\text { Std. Error } \\
\text { Difference }\end{array}$ & $\begin{array}{l}95 \% \text { Confi } \\
\text { Difference } \\
\text { Lower }\end{array}$ & $\begin{array}{l}\text { Interval of the } \\
\text { Upper }\end{array}$ \\
\hline TUBT & -.092 & 182 & .927 & -.01211 & .13156 & -.27170 & .24747 \\
\hline SUBT & -.135 & 182 & .893 & -.01447 & .10705 & -.22570 & .19675 \\
\hline SUBS & .503 & 182 & .616 & .05666 & .11268 & -.16567 & .27899 \\
\hline LATT & -2.365 & 182 & .019 & -.24164 & .10219 & -.44327 & -.04001 \\
\hline STDD & -.577 & 182 & .565 & -.08218 & .14241 & -.36317 & .19881 \\
\hline LEF & .204 & 182 & .838 & .02452 & .11996 & -.21218 & .26122 \\
\hline
\end{tabular}

Similar to the gender, independent-sample t-test was examined for the students of first semester and second semester. Results reveal that only significant difference was observed in the mean scores of LATT. More specifically score for the first semester were $\mathrm{M}=2.2637, \pm \mathrm{SD}=.70056$, and second semester were $\mathrm{M}=2.5054$, $\pm \mathrm{SD}=.68562 ; \mathrm{t}(184)=-2.364, \mathrm{p}=.019$, two-tailed. From the mean score it shows that first semester were more reluctant compare to the second semester in perceiving LATT (i.e., $1=$ strongly Agree to $5=$ strongly disagree).

Finally, for looking impact of the students perception based upon TUBT, SUBT, SUBS, STDD, and LEF on LATT regression analysis has been examined. Looking at the model summery table (Table 8), the total variance shared by all the independent variables into dependent variable (i.e., $\mathrm{R}^{2}$ ) is .266 or $26 \%$. Specifically looking at the individual variance shared by each variable (i.e., b-value), coefficient table (Table 9) reveals that out of five variables (TUBT, SUBT, SUBS, STDD, LEF) only STDD was insignificant $\mathrm{t}(184)=.842, \mathrm{~b}=.065$ or $6 \%, \mathrm{p}=.40$, 
whereas remaining others shown significant positive effect. Specifically, highest effect was observed of SUBS $(\mathrm{t}(184)=5.547, \mathrm{~b}=.407$ or $40 \%, \mathrm{p}=.000)$ followed by $\operatorname{SUBT}(\mathrm{t}(184)=2.192, \mathrm{~b}=.18$ or $18 \%, \mathrm{p}=.030)$.

Table 3. Model summary

\begin{tabular}{|c|c|c|c|c|}
\hline Model & $\mathrm{R}$ & R Square & $\begin{array}{l}\text { Adjusted R } \\
\text { Square } \\
\end{array}$ & Std. Error of the Estimate \\
\hline 1 & $.515^{\mathrm{a}}$ & .266 & .245 & .60968 \\
\hline
\end{tabular}

Table 4. Coefficients ${ }^{\mathrm{a}}$

\begin{tabular}{|c|c|c|c|c|c|c|c|c|}
\hline \multirow{2}{*}{\multicolumn{2}{|c|}{ Model }} & \multicolumn{2}{|c|}{$\begin{array}{l}\text { Unstandardized } \\
\text { Coefficients }\end{array}$} & \multirow{2}{*}{$\begin{array}{l}\text { Standardized } \\
\text { Coefficients } \\
\text { Beta } \\
\end{array}$} & \multirow[t]{2}{*}{$\mathrm{t}$} & \multirow[t]{2}{*}{ Sig. } & \multicolumn{2}{|c|}{$95.0 \%$ Confidence Interval for B } \\
\hline & & B & Std. Error & & & & Lower Bound & Upper Bound \\
\hline \multirow{6}{*}{1} & (Constant) & .956 & .211 & & 4.519 & .000 & .538 & 1.373 \\
\hline & TUBT & .134 & .067 & .170 & 2.009 & .046 & .002 & .266 \\
\hline & SUBT & .174 & .080 & .180 & 2.192 & .030 & -.331 & -.017 \\
\hline & SUBS & .374 & .067 & .407 & 5.547 & .000 & .241 & .507 \\
\hline & STDD & .048 & .057 & .065 & .842 & .401 & -.064 & .159 \\
\hline & LEF & .109 & .062 & .126 & 1.742 & .083 & -.014 & .232 \\
\hline
\end{tabular}

\section{Conclusion and Recommendations}

The low competence in all skills of English language as a foreign language in general and speaking English in particular could be attributed to several factors in the EFL context of Saudi Arabia. Thus, it's not easy to address the problems in speaking skills faced by Saudi EFL learners. The current study aimed at investigating the impact of various factors on the attitude of the learners in learning speaking skills to developing understanding about the factors underlying this problem.

On the whole, the mean value for five out of the six constructs is above the neutral value of 2.5 which state that opinion of the respondents was moderate telling that teaching speaking and learning it was not done well in the EFL context of Taif University. 2.46 was the least mean value noticed for only one construct "strategies used by the teachers" (SUBT). This is just below the neutral value. In this way, it could be inferred that lack of measures on the part of teachers and learners as well as the classroom setting/environment do not fully support or facilitate both the male and female students to learn speaking skills in a better way. The poor level of their skills in English is attributed to all these factors. And these factors, as results show, affect negatively on the attitude of learners towards learning speaking skills. The results of regression model show that out of five variables (TUBT, SUBT, SUBS, STDD, LEF) only STDD was insignificant $\mathrm{t}(184)=.842, \mathrm{~b}=.065$ or $6 \%, \mathrm{p}=.40$, whereas remaining others show significant positive effect on the attitude of learners. Since the attitude is outcome of motivation, it's very important to control the negative impact of these factors on the motivation of the Saudi EFL learners in Taif University for teaching and learning speaking skills.

With regard to the use of strategies in practice, the findings based on the responses of the students tell that teachers don't quite often utilize important strategies such designing good speaking activities, utilizing learners-centered approach and sparing enough time for ample speaking practice. The teachers use sometimes only a couple of less significant strategies such as asking for feedback about mistakes correction and assisting them in pronunciation. Students do not agree that they are motivated to learn English and have confidence in speaking it. Their attitude towards learning English as a foreign language is not positive as they prefer to use their mother tongue and has developed negative attitude towards the culture of native speakers of English. Most of students report that they are worried about making mistakes and feel pressurized for better performance. They are not given plenty of time to perform a speaking task in the class and haven't a good knowledge of English grammar that led me (them) construct errors free sentences when speaking. In addition to this, the classroom setting doesn't facilitate the frequent practice of speaking skills because learning resources for speaking are a few and students don't have frequent have access to audio and visual aids and there are a few language labs which are not easily accessible for teachers to do the practice of speaking skills.

The results of this study, corresponding with the observation made in the research on learner individual variables influence on their motivation (Lightbown \& Spada, 2013), show that low performance in speaking the foreign 
language is caused by internal and external factors. In addition to this, the findings of this research are in line with the results of the study by Brophy (2004) that students come with motivation and feel enthusiast to learn, but when they start facing certain external practices such as techniques and strategies used by the teachers and difficulties they face in learning speaking skills are highly demotivated. This study is aligned with results of Horwitz (2008) whose study shows that leaners face a great deal of difficulties to develop better speaking skills due to anxiety. Additionally, the findings also corroborate with research of Liu \& Jackson (2008) who also identified anxiety as a problem among undergraduates in oral English skills in China.

The results of the study are also found consistent with the findings of Alrabai (2014) and Khan (2011) that distinctive feature that negatively affects Saudi EFL learners' ability to learn English is a lack of motivation. The findings of the current study found a positive relation between other factors such as TUBT, SUBT, SUBS, STDD and LEF on the attitude and motivation of learners towards learning English. Khan (2011) also maintained that Saudi EFL learners' lack of motivation hinders them to develop proficiency in speaking English. Negative attitude to learning speaking English are attributed to diverse and complex factors, the main reasons, according to the findings of this study are that the most common technique used by teachers is "questioning and answering" and "giving instruction on given topics" instead of utilizing "picture description" and "conversation or dialogues project" and "role play and drama". The less frequent use of such techniques affect negatively on the attitude of learners towards learning speaking skills.

According to Al-Khairy (2013), the factors that negatively affect university undergraduates in Saudi Arabia are peer pressure, inappropriate teaching methods, insufficient utilization of modern teaching aids, and the difficulty they have in using appropriate vocabulary and correct use of grammar. The results of the current study also confirmed that students are worried about making mistakes and feel pressurized for better performance in the class. They don't have a good knowledge of English grammar so they are unable construct errors free sentences when speaking. According to Khan (2011), another factor which demotivates students is the lack of support offered by the teachers in the classroom. This factor was also highlighted in the students' response that teacher don't give much support and spare enough time for the practice of speaking English in the class. It's also reported in the research study by Aljumah (2011) that Saudi students get fewer opportunities to practice English in the class. Even if they find chance to communicate in the class they don't avail this chance or speak very little. This is one of the important reasons why students feel difficulty while communicating in the target language.

\subsection{Significance and Recommendations}

The lack of research about leaners' experience of speaking skills is a main problem. There is not much literature available to guide us on how to help leaners cope with this challenging skill. The current study seeks to fill in this gap by contributing to the existing body of literature by investigating the impact of various internal and external factors on the attitude of learners towards speaking English.

The present study has helped develop understanding on the important area of EFL in the context of KSA which has almost been untouched except a few studies which of them have largely been conducted in the learning context of the USA about Saudi English learners studying there. In this way, the findings of the present study could be useful not only for the teachers and leaners of TAIF University but for all the EFL leaners and English professionals of all the universities in KSA.

The findings of the current study are significant for the teaching and learning context of TUELC where it is conducted. Based on the understanding developed through this study about the challenges and difficulties faced by the leaners in speaking skills, English professionals can improve their pedagogical practices of teaching speaking skills. Since the present study takes into consideration the significance of external factors in addition to the academic and instructional, English professionals, policy makers and syllabus designers can take guidance from the findings for making better decisions to improve teaching and learning of speaking skills. The findings of the present study could also help leaners to employ better strategies and approaches for improving their speaking skills at TUELC other than they are already using.

On the basis of the findings of the current study, it's recommended that teachers use all important techniques and strategies to help learners develop better speaking skills in English. The lack of practicing important techniques and strategies affect negatively on the attitude of learners. Their role is pivotal in this regard. In addition to this, teachers may also encourage the learners to utilize the important student strategies in and outside the class room so that they may develop do the practice and develop their skills. It's also suggested to utilize the post-method pedagogies as they were found very useful by the teachers in the EFL context of Saudi Arabia (Soomro \& Almalki, 2017). To make the most of such important techniques and strategies, teachers and students must be facilitated in terms of improving learning environment and providing 
necessary facilities.

To give exposure to the language, it's important that teachers and students must conduct classroom interactions in the target language. Use of Arabic, the first language, should be minimized and rather be restricted as much as possible until the use of English becomes prevalent. As mentioned earlier, practicing English outside the classroom must also be encouraged by asking the learners using different available types of media such as social (Facebook/Twitter/WhatsApp) and English-language (News channels/Documentaries/Science fiction movies). Students should have access to an English library as well as online sources in the language $\mathrm{Lab}$ as a scheduled classroom activity under the supervision of the teachers so that students get used to it and develop habit of utilizing such information and knowledge in their practice of speaking skills.

\section{Acknowledgments}

We acknowledge the financial support offered by Taif University to complete this research project. I also acknowledge the role and contribution of the co-author in this article.

\section{References}

Akasha, O. (2013). Exploring the Challenges Facing Arabic-Speaking ESL Students \& Teachers in Middle School. Journal of ELT and Applied Linguistics (JELTAL), 1(1), 12-31.

Aljumah, F. (2011). Developing Saudi EFL Students' Oral Skills: An Integrative Approach. English Language Teaching, 4(3), 84-89. https://doi.org/10.5539/elt.v4n3p84

Al-Khairy, M. (2013). English as a foreign language learning demotivational factors as perceived by Saudi undergraduates. European Scientific Journal, 9, 365-382.

Al-khresheh, M. (2010). Interlingual interference in the English language word order structure of Jordanian EFL learners. European Journal of Social Sciences, 16(1), 106-113

Alrabai, F. (2014). Motivational practices in English as a foreign language classes in Saudi Arabia: Teachers beliefs and learners perceptions. Arab World English Journal, 5(1), 224-246.

Brophy, J. (2004). Motivating students to learn (2nd ed.). London: Lawrence Erlbaum Associates.

Burns, A. (2001). Analysing Spoken Discourse: Implications for TESOL. In A. Burns \& C. Coffin (Eds.), Analysing English in a Global Context: A Reader (pp. 123-148). London: Routledge.

Burns, A., \& Seidlhofer, B. (2010). Speaking and Pronunciation. In N. Schmitt (Ed.), An Introduction to Applied Linguistics (pp. 197-214). London: Hodder Education.

Bygate, M. (1998). Theoretical Perspectives on Speaking. Annual Review of Applied Linguistics, 18, $20-42$. https://doi.org/10.1017/S0267190500003469

Byrne, D. (1991). Techniques for Classroom Interaction. Cambridge: Cambridge University Press.

Cao, Y. (2011). Investigating Situational Willingness to Communicate within Second Language Classrooms from an Ecological Perspective. System, 39, 468-479. https://doi.org/10.1016/j.system.2011.10.016

Celce-Murcia, M., \& Olshtain, E. (2000). Discourse and Context in Language Teaching. Cambridge: Cambridge University Press.

Chot, P. (2015). Factors Affecting Students' Learning English Speaking Skills: A Case of second year students of English Department in Gambella College of Teachers Education (MA dissertation, AddisAbaba University).

Cotter, Ch. (2007). Speaking well—four steps to improve your ESL EFL students speaking ability.

Cotterall, S., \& Crabbe, D. (1999). Learner autonomy in language learning: Defining the field and effecting change. Switzerland: Peter Lang. https://doi.org/10.3726/978-3-653-02293-3

Cronbach, L. J. (1951). Coefficient alpha and the internal structure of tests. Psychometrika, 16(3), 297-334. https://doi.org/10.1007/BF02310555

Ferris, D. (1998). Students Views of Academic Aural/Oral Skills: A Comparative Needs Analysis. TESOL Quarterly, 32, 289-318. https://doi.org/10.2307/3587585

Ferris, D., \& Tagg, T. (1996). Academic listening/speaking tasks for ESL students: Problems, suggestions, and implications. Tesol Quarterly, 30(2), 297-320. https://doi.org/10.2307/3588145

Gashaw, A. (2017). Rhythm in Ethiopian English: Implications for the Teaching of English Prosody. 
International Journal of Education \& Literacy Studies, 5(1). https://doi.org/10.7575/aiac.ijels.v.5n.1p.13

Harmer, J. (2001). The practice of English Language Teaching. Edinburgh: Pearson Education Limited.

Hedge, T. (2001). Teaching and learning in the language classroom (Vol. 106). Oxford, UK: Oxford University Press.

Horwitz, E. K. (2008). Becoming a Language Teacher: A Practical Guide to Second Language Learning and Teaching. Harlow: Pearson Education. (Kawai 2008).

Kim, S. (2006). Academic Oral Communication Needs of East Asian International Graduate Students in Non-science and Non-engineering Fields. English for Specific Purposes, 25, 479-489. https://doi.org/10.1016/j.esp.2005.10.001

Khan, I. (2011). Learning difficulties in English: Diagnosis and pedagogy in Saudi Arabia. Educational Research, 2(7), 1248-1257.

Levelt, W. (1989). Speaking: From Intention to Articulation. Cambridge: MIT Press.

Lightbown, P. M., \& Spada, N. (2013). Oxford Handbooks for Language Teachers: How Languages Are Learned (4th ed.). Oxford: Oxford University Press.

Li, D. F. (1998). It's Always More Difficult than You Plan and Imagine: Teachers' Perceived Difficulties in Introducing the Communicative Approach in South Korea. TESOL Quarterly, 32, 677-703. https://doi.org/10.2307/3588000

Lin, H. (1998). Different attitudes among non-English major EFL students. The Internet TESL Journal, 4(10), $1-9$.

Littlewood, W. (2007). Communicative and Task-based Language Teaching in East Asian Classrooms. Language Teaching, 40, 243-249. https://doi.org/10.1017/S0261444807004363

Liu, M., \& Jackson, J. (2008). An Exploration of Chinese EFL Learners' Unwillingness toCommunicate and Foreign Language Anxiety. Modern Language Journal, 92, 71-86. https://doi.org/10.1111/j.1540-4781.2008.00687.x

McCarthy, M., \& O'Keeffe, A. (2004). Research in the Teaching of Speaking. Annual Review of Applied Linguistics, 24, 26-43. https://doi.org/10.1017/S0267190504000029

MacIntyre, P. D., Clement, R., Dornyei, Z., \& Noles, K. A. (1998). Conceptualizing Willingness to Communicate in a L2: A situational Model of L2 Confidence and Affiliation. The Modern Language Journal, 81, 545-562. https://doi.org/10.1111/j.1540-4781.1998.tb05543.x

Morita, N. (2000). Discourse Socialization through Oral Classroom Activities in a TESL Graduate Program. TESOL Quarterly, 4, 279-310. https://doi.org/10.2307/3587953

Norton, B. (1995). Social Identity, Investment, and Language Learning. TESOL Quarterly, 29, 9-31. https://doi.org/10.2307/3587803

Norton, B. (1997). Language, Identity, and the Ownership of English. TESOL Quarterly, 31, 409-429. https://doi.org/10.2307/3587831

Norton, B., \& Toohey, K. (2001). Changing Perspectives on Good Language Learners. TESOL Quarterly 35, 307-332. https://doi.org/10.2307/3587650

Nunnally, J. C. (1978). Psychometric theory (2nd ed.). New York: McGraw-Hill.

Nunan, D., \& Lamb, C. (1996). The self-directed teacher: Managing the learning process. Cambridge: Cambridge University Press.

Palmer, B. C., El-Ashry, F., Leclere, J. T., \& Chang, S. (2007). Learning from Abdallah: A Case study of an Arabic-speaking child in a U.S. school. The Reading Teacher, 61(1), 817. https://doi.org/10.1598/RT.61.1.2

Pawlak, M., Waniek-Klimczak, E., \& Majer, J. (2011). Speaking and Instructed Foreign Language Acquisition. Clevedon: Multilingual Matters.

Ramirez, V. A. C. (2010). Students' Perceptions about the Development of their Oral Skills in an English as a Foreign Language Teacher Training Program.

Richards, J. C., \& Renandya, W. A. (Eds.). (2002). Methodology in language teaching: An anthology of current practice. Cambridge: Cambridge university press. https://doi.org/10.1017/CBO9780511667190 
Scharle, A., \& Szabó, A. (2000). Learner autonomy: A guide to developing learner responsibility. Ernst KlettSprachen.

Skehan, P. (2001). Tasks and Language Performance Assessment. In M. Bygate, P. Skehan, \& M. Swain (Eds.), Researching Pedagogic Tasks, Second Language Learning, Teaching and Testing (pp. 167-185). Harlow: Longman.

Skehan, P. (2009). Modelling Second Language Performance: Integrating Complexity, Accuracy, Fluency, and Lexis. Applied Linguistics, 30, 510. https://doi.org/10.1093/applin/amp047

Soomro, A. F., \& Almalki, M. S. (2017). Language Practitioners' Reflections on Method-Based and Post-Method Pedagogies. English Language Teaching, 10(5), 234-242. https://doi.org/10.5539/elt.v10n5p234

Ur, P. (1996). A Course in Language Teaching: Practice and Theory. Cambridge: Cambridge University Press.

Wenden, A. (1991). Learner strategies for learner autonomy. New York.

Yang, L. (2010). Doing a Group Presentation: Negotiations and Challenges Experienced by Five Chinese ESL Students of Commerce at a Canadian University. Language Teaching Research, 14, 141-160. https://doi.org/10.1177/1362168809353872

Yashima, T. (2002). Willingness to communicate in a second language: The Japanese EFL context. The Modern Language Journal, 54-66. https://doi.org/10.1111/1540-4781.00136

\section{Copyrights}

Copyright for this article is retained by the author(s), with first publication rights granted to the journal.

This is an open-access article distributed under the terms and conditions of the Creative Commons Attribution license (http://creativecommons.org/licenses/by/4.0/). 